\title{
A Comprehensive Review on Maerua Oblongifolia (Forsk.) A. Rich.
}

\author{
Bhalakiya Hetal laxmichand ${ }^{1}$, Dr. Nainesh Rajendra Modi ${ }^{2}$ \\ ${ }^{1}$ Ph.D. Reaserch scholar, ${ }^{2}$ Associate Professer (Botany) \\ ${ }^{1,2}$ Department of Botany, Bioinformatics and Climate change impacts Management school of science \\ Gujarat University, Navrangpura, Ahemdabad-380009, India.
} Email: bhalakiyahetal@gmail.com

\begin{abstract}
Murva is a significant ayurvedic drug used as one of the ingredients in many Ayurvedic preparations. Maerua oblongifolia (Forsk.) A. Rich. (Capparaceae) is one of the botanical sources of the Ayurvedic drug Murva. Maerua oblongifolia (Forsk.) A. Rich. is an important ayurvedic drug used in many Ayurvedic preparations. It is locally known as Orapa, belong to Capparaceae family. Traditionally Maerua oblongifolia (Forsk.) A. Rich. is used to treat various diseases such as fever, stomach ache, skin infections, diabetes mellitus, epilepsy and abdominal colic. In present paper detailed taxonomic description, photographs, Botanical characters and its phytochemical inside are discuss.
\end{abstract}

Keywords: Phytochemicals, Maerua oblongifolia (Forsk.) A. Rich, Drug.

\section{INTRODUCTION:}

Murva is an important ayurvedic drug use as one of the ingredient in many Ayurvedic preparations. Maerua oblongifolia (Forsk.) A. Rich. (Capparaceae) is one of the botanical sources of the Ayurvedic drug Murva. The accepted botanical source is Marsdenia tenacissima(Roxb.) Moon. Ethanomedical survey reveals that Murva is used to cure various diseases such as fever, stomach ache, skin infections, urinary calculii, diabetes mellitus, epilepsy, pruritis, rigidity in lower limbs, and abdominal colic. In India, the Ayurvedic systems of medicine has been existing for over three thousand years, Charaka and Sushruta, two of the most primitive Indian scholars had sufficient knowledge of the properties of the Indian medicinal plants. The Vedas are the epic poems, which contain rich material on the herbal medicine of that time [1].The medicinal treatises like the Charakasamhita and Sushrutasamhita are esteemed even to this day as the treasures of literature on indigenous medicine [2] . Murva is a notorious drug. Amongst the many synonyms of this plant, one is 'Dhanurgunopayogya' meaning 'the plant whose bark is being used for the bow-strings'. These synonyms have also contributes to the existing confusion. The plant which has tough fibres is the Murva? There are many such fiber yielding plants are found in the vegetable kingdom. Murva is an important controversial drug used in diseases like anaemia (pandu); fever (jwara); diabetes (prameha); stomach disorder (udara roga); typhoid (visama jwara); urinary infection (asmari) and cough (ksaya) [3] . The third world nations of Asia are rich in biodiversity and original knowledge particularly ethnomedicinal practices.[4] The researchers all over the world are functioning in drug discovery explore from medicinal plants which are on behalf of a rich source of antimicrobial agents. However, many of the plant materials used in traditional medicine are readily available in rural areas at relatively cheaper than modern medicine.[5] India is able with a rich biological heritage and possesses more than 53 million tribal people belonging to 300 tribal community, constituting about $8 \%$ of the total population of the country.[6] In India, the Ayurvedic systems of medicine has been existing for over three thousand years, Charaka and Sushruta, two of the earliest Indian scholars had enough knowledge of the properties of the Indian medicinal plant life. The Vedas are the epic poems, which contain rich material on the herbal medicine of that time People living in tribal localities and in villages are using local plants as medicines from long ago because this knowledge reach to them through generation to generation, and is based on experience $[7,8]$. One of the significant medicinal plant is Maerua oblongifolia (Forsk.) A. Rich. (Capparaceae) is locally known as Orapa in Rajasthan. It is a endangered plant in the area. Plant is woody climber and climbs over Prosopis cineraria, Maytenus emarginata, Tecomella undulata, Salvadora spp. and resembles Cocculus species. Plants produce fragrant flowers during summers. The ripe fruits are sugar rich, sweet with high calorific value and are rarely seen as these are eaten by squirrels and birds. Maerua oblongifolia (Forsk.) A. Rich due to its eyecatching aromatic flowers can be developed as garden and ornamental plant. Murva is an important ayurvedic drug use as one of the ingredient in many Ayurvedic preparations. Maerua oblongifolia (Forsk.) A. Rich. (Capparaceae) is one of the botanical sources of the Ayurvedic drug Murva. The accepted botanical source is Marsdenia tenacissima(Roxb.) Moon. Ethanomedical survey reveals that Murva is used to cure various 


\section{Available online at www.ijrat.org}

diseases such as fever, stomach ache, skin infections, urinary calculii, diabetes mellitus, epilepsy, pruritis, rigidity in lower limbs, and abdominal colic. In India, the Ayurvedic systems of medicine has been existing for over three thousand years, Charaka and Sushruta, two of the most primitive Indian scholars had sufficient knowledge of the properties of the Indian medicinal plants. One of the significant medicinal plant is Maerua oblongifolia (Forsk.) A. Rich. (Capparaceae) is locally known as Orapa in Rajasthan. It is a endangered plant in the area. Plant is woody climber and climbs over Prosopis cineraria, Maytenus emarginata, Tecomella undulata, Salvadora spp. and resembles Cocculus species. Plants produce fragrant flowers during summers. The ripe fruits are sugar rich, sweet with high calorific value and are rarely seen as these are eaten by squirrels and birds. Maerua oblongifolia (Forsk.) A. Rich due to its eye-catching aromatic flowers can be developed as garden and ornamental plant. $M$. oblongifolia is highly drought and high temperature resistant therefore it can be a potential target for gene prospecting. Plant provides shelter and food to birds and animals [9]. It is used to cure various diseases such as fever, stomach ache, skin infections, urinary calculii, diabetes mellitus, epilepsy, pruritis, rigidity in lower limbs, and abdominal colic [10]. This plant always grow in association with some specific tree species, as the population of these trees is decreasing day by day due to their over exploitation for fodder, food, timber and for medicinal purposes the plant of Maerua oblongifolia (Forsk.) A. Rich is also facing threat of extinction. Moreover, the plant propagates in nature through seeds. The viability of these seeds is less and most of the seeds are eaten up by the rodents. [10] So, there is an urgent need for the conservation of this valuable plant.

\author{
2. TAXONOMICAL CLASSIFICATION \\ Kingdom: Plantae \\ Order: Brassicales \\ Family: Capparaceae \\ Genus: Maerua \\ Species: M. oblongifolia
}

\subsection{The plant is named in different vernacular languages.}

Unani: Harasingaar.

Hindi: Hemkand, Potiakand, Wagboti

Tamil: Bhumichakkarai

Gujrat: Hemkand, Kala-pinjola

Punjab: Pilwani

Rajasthan: Orapa

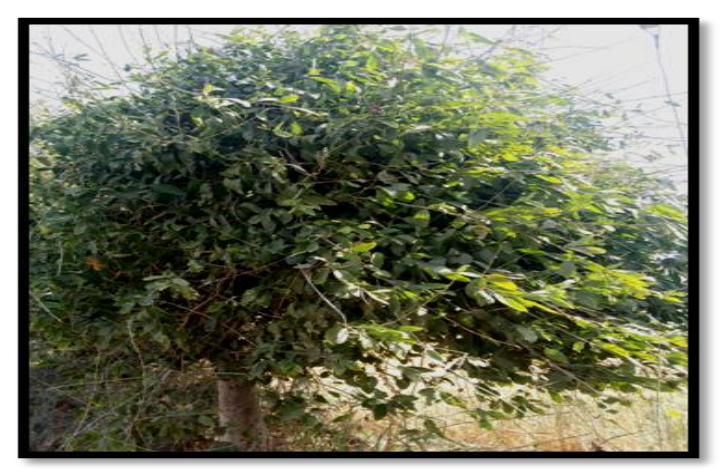

(1) Whole plant

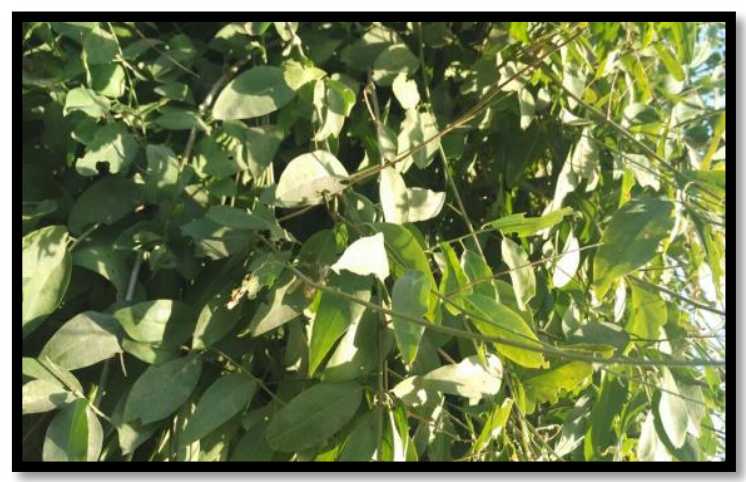

(3) Leaves part

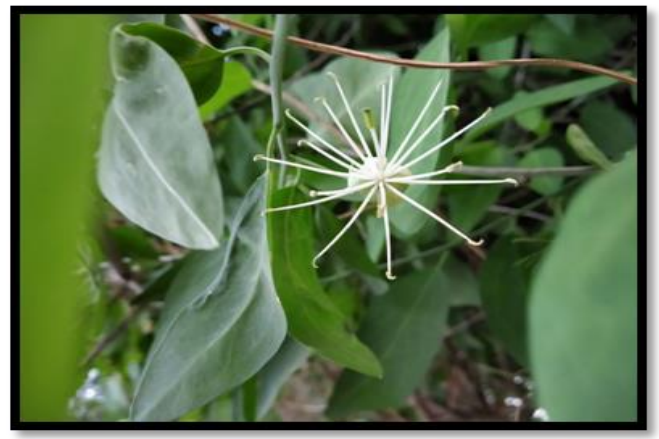

(2) Flowering part



(4) Fruit nart

Fig 1: Images of Maerua oblongifolia Plant 


\section{Available online at www.ijrat.org}

\subsection{Botanical characters:}

A large woody climbing shrub, unarmed, often scandent with pale brown and smooth bark. Leaves petiolate, from time to time clustered on shortened lateral shoots, simple or 1 - 3 foliolate, stipules minute, subulate. Flowering in February to March. Flowers greenish white, corymbs, sometimes 1 - 4 in axils of upper leaves. Sepals 4, rarely 3 , valvate, united at base, caducous, calyx forming 4-6 mm long tube, sharply lined by receptacle. Petals 3 - 4, hardly ever absent, equal, smaller than calyx, inserted at throat of calyxtube, mostly caducous. Receptacle cylindrical, campanulate or infundibular, inner margin formed into a lobed or toothed disc. Stamens many, exert, close to the middle of torus, filaments free, or basally connate with gynophore. Gynophore long exceeding stamens, ovary cylindric to ellipsoid, 1- 2 - locular, stigma subsessile, capitate, parietal placentae. Fruits are pale-brown, 8 to $12 \mathrm{~cm}$ long, tight between the seeds, forming an elongated, twisted and knotted berry; each knot is one- seeded. This plant exhibit wide variation in fruit size and morphology [11].

\section{PHYTOCHEMICALS PRESENT IN THE Maerua oblongifolia (FORSK.) A. RICH - THE CONCERNS OF RESEARCHERS:}

The phytoconstituents reported in Maerua oblongifolia (FORSK.) A. RICH compounds like lupine triterpenoid, betulin and betulinaldehyde have been found [12] Preliminary phytochemical studies of the roots of Maerua oblongifolia (FORSK.) A. RICH contained alkaloids, carbohydrates, glycosides, phytosterols, saponins, proteins and amino acids Maerua oblongifolia (FORSK.) A. RICH stem bark possesses wound-healing activity $[13,14]$ and is used to treat toothache and intestinal disorders [15]. Three lupane triterpenoid were isolated and characterized from Maerua oblongifolia (FORSK.) A. RICH by one and two dimensional NMR, MS and IR spectra, as lup-20(29) - 30-diol [16, 17].

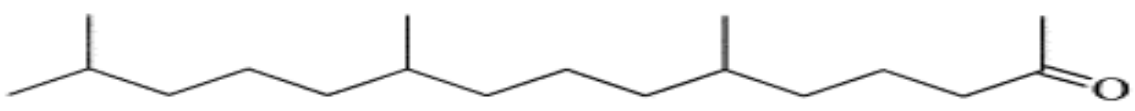

$\mathbf{1}$

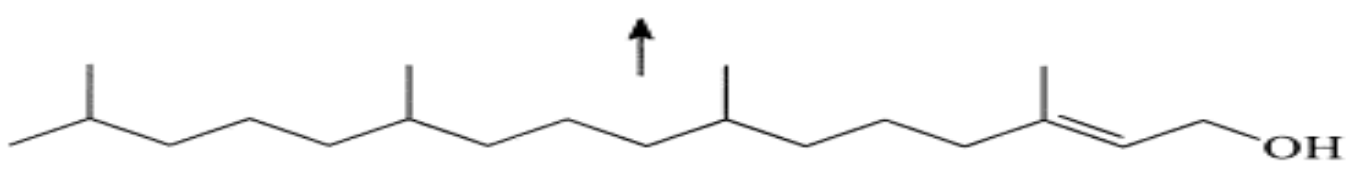

2



3; $\mathrm{R}^{\prime}=\mathrm{CH}_{2} \mathrm{OH}, \mathrm{R}^{\prime \prime}=\mathrm{CH}_{3}$

4; $\mathrm{R}^{\prime}=\mathrm{CHO}, \mathrm{R}^{\prime \prime}=\mathrm{CH}_{3}$

5; $\mathrm{R}^{\prime}=\mathrm{CH}_{3}, \mathrm{R}^{\prime \prime}=\mathrm{CH}_{2} \mathrm{OH}$

Figure 2: Lupane triterpenoid structure 
International Journal of Research in Advent Technology, Vol.7, No.4, April 2019

E-ISSN: 2321-9637

Available online at www.ijrat.org

\section{PHARMACOLOGICAL ACTIVITIES AND MEDICINAL USE OF Maerua oblongifolia (FORSK.) A. RICH \\ 4.1 Antipyretic activity studies}

A reduction in the rectal temperature of febrile rats, treated with different doses of the aqueous and alcoholic extracts of the drugs, was recorded at $30,60,120,180$ and 300 min post-administration. The reduction in the rectal temperature of the treated animals at each interval was compared with that exhibited by the untreated febrile rats. The alcoholic and aqueous extracts of both drugs produced significant antipyretic effects M. oblongifolia $(\mathrm{P}<0.05)$, within $30 \mathrm{~min}$ of administration. The maximum temperature reduction was observed at $120 \mathrm{~min}$ for Maerua oblongifolia (FORSK.) A. RICH. The results were dose-dependent in Maerua oblongifolia (FORSK.) A. RICH.; however, there was a significant reduction in the rectal temperature of febrile rats after all time intervals for both drugs [18].

\subsection{Antioxidant activity:}

The antioxidant properties of the crude extracts were tested using (DPPH) photometric assay according to the standard methods with some modifications [19]. DPPH is a stable free radical that can accept an electron or hydrogen radical to become stable diamagnetic molecule. The radical scavenging potential of extracts and their fractions are determined by measuring the decrease in absorbance due to DPPH at $517 \mathrm{~nm}$, representing the formation of its reduced form, Diphenyl picryl hydrazine (DPPH), which is yellow in color. Because of the odd electron, the purple colourethanolic solution shows a strong absorption at $517 \mathrm{~nm}$. A leaves of methanol extract of Maerua oblongifolia (FORSK.) A. RICH. (71 \pm 0.05$)$, IC50 was calculated for all active extracts (four extracts) using different extracts concentration: 50, 25, 12.5, 6.25 and $3.125 \mu \mathrm{g} / \mathrm{ml}$, and the results obtained indicated that the lowest IC50 was obtained from the leaves of methanol extract of Maerua oblongifolia (FORSK.) A. RICH. $(28.3 \pm 0.31) \mu \mathrm{g} / \mathrm{ml}$. The chemical groups detected in these extracts include alkaloids, flavonoids, tannins, saponins, Coumarins, triterpens and Steroids, which are suggested to be responsible for their bioactivity [20]. 2,2-diphenyl-1-picrylhydrazyl (DPPH) is stable free radical substance, which is reduced to diphenyl picrylhydrazineb when it reacts with an antioxidant agent. Antioxidants interrupt free radical chain oxidation by donating hydrogen from hydroxyl group to form a stable end product, which does not commence or propagate additional oxidation of lipids in human body [21].

\subsection{Antimicrobial and Antibacterial activity:}

Methanolic and Chloroform extract of the Maerua oblongifolia (FORSK.) A. RICH. leaves were investigated for in-vitro bactericidal activities against (Staphylococcus aureus American Type Culture Collection ATCC 25923 and Bacillus subtilus National Culture Type Collection NCTC 8236), Gram negatie bacteria (Escherichia coli ATCC 25922, and Salmonella typhi NCTC 0650) and fungi (Aspergillus niger ATCC 9763 and Candida albicans ATCC 7596) using agar well diffusion method (NCCLS, 2000) and the resulting inhibition zones were measured and tabulated as means. Both extracts were active it was also observed that, Bacillus subtilus and Escherichia coli were the most sensitive microorganism inhibited by all extracts followed by Salmonella typhi and Staphylococcus aureus were inhibited by chloroform extracts only. While Candida albicans inhibited by stem extracts and resist to leave extracts. Furthermore, all of the stem chloroform extracts exhibit inhibitory activity against the entire tested organism with zones of inhibition ranging from 13-20 mm. Moreover, Aspergillus niger was superior and sensitive against all of the tested extracts with high inhibition zone of $19 \mathrm{~mm}$. The major inhibition zone (20 $\mathrm{mm}$ ) obtained from stem chloroform extracts against Escherichia coli. The Minimum Inhibitory Concentrations (MICs) of the most active extracts were determined against position organisms (Staphylococcus aureus, Bacillus subtilus, Escherichia coli, Salmonella typhi, Candida albicans and Aspergillus niger) it was create that MICs a ranging between concentration $2.5-5 \mathrm{mg} \backslash \mathrm{mL}$. The extracts derived from chloroform extracts were more active than methanol extracts. This may indicate that the non polar active principles are responsible for the antimicrobial activity in Maerua oblongifolia (FORSK.) A. RICH. This result agrees with many previous researches that reported the bioactivity of non polar principles in plants like Achillea santolina, Typhonium flagelliforme, Schisandra sphenanthera, and Scutellaria barbata $[22,23,24]$ The inhibitory activities exhibited by the extracts tend to agree with the reports of $[25,26]$ all whom linked antimicrobial property of plants to the presence of bioactive secondary metabolites. The study also showed that these plants may be good quality as an antibacterial and antifungal recipe and not toxic.

\subsection{Cytotoxicity activity:}

The antiproliferative activity of plant extracts are measure using MTT (3-(4,5-dimethylthiazol-2-yl)-2,5diphenyltetrazolium bromide) assay . The assay detects the reduction of MTT by mitochondrial dehydrogenate 
to blue formazan creation which reflects the normal function of mitochondria and cell viability. In vitro cytotoxicity assay are perform as described by [27] using the $3 \mathrm{~T} 3 \mathrm{NIH}$ mouse embryo fibroblast cell line and $\mathrm{CC}-1$, a rat Wistar hepatocyte cell line, from European Collection of Cell Cultures, (Salisbury, UK) .In vitro cytotoxicity assays using the $3 \mathrm{~T} 3 \mathrm{NIH}$ mouse embryo fibroblast cell line and CC-1, a rat Wistar hepatocyte cell line calculated by MTT indicate that, all extracts of leaves and stems is non toxic for 3 T3 And CC-1 cell line with IC50>100 $\mu \mathrm{g} / \mathrm{ml}$. The least a viability of CC-1 was $112.26 \%$, whereas, the negative control was $100 \%$ and the positive control was $32.95 \%$, while the least a viability of $3 \mathrm{~T} 3$ was $80.6 \%$. Antimicrobial activities shown by plant extracts and some nutritional value in CC-1 normal cell line is could have due to the presence of bioactive substances in these plants, the introduction phytochemical constituents studies showed the presence of triterpenoids and alkaloids [28]. Since prehistoric times, public have use natural property for medicinal purposes.

\subsection{Antiviral activity:}

Antiviral phytochemical s were profoundly affected by various reaction parameter $s$ as was reported by [29] who found that, the activities o f several know $n$ antiviral phytochemical s were affected $b$ y the presence o f serum components . Methanolic extract had a different degree of inhibitory activity and specificity against the virus and/o $r$ its essential enzymes. Also, it ma $y$ b e due $t$ o the fact that, most o f the plant $s$ showing antiviral activity were found t o contain some proteinaceous substance $\mathrm{s}$ or polypeptide as reported [30]. These plant proteins have been reporte to act against the viruses by inhibiting their protein synthesis. These findings are significant because serum is commonly used in virus assays, and plant extracts often contain polypeptides. Furthermore, when phytochemical $\mathrm{s}$ are used in vivo, their effect $\mathrm{s}$ could be modulate $\mathrm{d}$ by $\mathrm{t}$ $\mathrm{h}$ e component $\mathrm{s}$ o f tissues and body fluids. $\mathrm{T} \mathrm{h}$ e reactions are also strongly affected by the order o $\mathrm{f}$ incubation of the components, virus compound $\mathrm{s}$ or extracts, serum, and UV-light. T h e bioassay technique followed ma y also has a great affect on the inhibitor $y$ potential. Antiviral s as well 1 as other compound s with indirect antiviral activities ma $\mathrm{y}$ have various mechanism s of action.

\subsection{Anti-diabetic activity:}

Anti-diabetic study Male Wistar strain rats by normal blood sugar level weighing between 120-180g were used for investigation. The animals are inject with alloxan monohydrate dissolve in distill water at a dose of $150 \mathrm{mg} / \mathrm{kg}$ body weight intraperitoneally to induce diabetes. After three days of injecting alloxan monohydrate, diabetes was confirmed by testing blood glucose sugar level using Abbott glucometer. The animals through blood glucose level more than $200 \mathrm{mg} / \mathrm{dl}$ are chosen for evaluation of anti-diabetic activity. Continued administration of roots extract of Murva $(800 \mathrm{mg} / \mathrm{kg})$ p.o and glibenclamide for 3 days in different group of diabetic rats formed significant reduction of blood glucose level. The test extract at a dose of $800 \mathrm{mg} / \mathrm{kg}$ p.o show potent anti diabetic activity $(\mathrm{p}<0.001)$ compared to standard drug Glibanclamide $(20 \mathrm{mg} / \mathrm{kg})$ i.p, normal control and diabetic control. It reduced blood glucose more than that of standard drug. [31].

\section{CONCLUSION:}

Maerua oblongifolia (Forsk.) A. Rich is a significant ayurvedic drug use in many ayurvedic preparations. The plant is used to treat various diseases such as stomach ache, urinary calculii, diabetes mellitus, skin infections, epilepsy, pruritis, fever etc. The medicinal plants can be protected by the protection program by help of local people. Native people maintain their health through the use of various plants as medicine and have developed a close association to the plants world. Often chemical screening of medicinal plant and their useful parts collected from the fields in different seasons should be also done. Moreover, to prevent the extinction of medicinal species, hard work may be made to grow the sensitive species by acclimatize them and if necessary them in situ as many species can be considered as an asset for human beings [32] .Very few works have been report on this valuable medicinal plant. Therefore, more work is needed to isolate the bioactive components of these plants. The above work cited in the article of phytochemicals and promising pharmacological activities are widely distributed in medicinal plant of Maerua oblongifolia (Forsk.) A. Rich and it revealed the importance of herbal and ayurvedic pathway for effective treatment of various diseases considering its tremendous potential pharmacological activities. Animal studies enlighten on anti-pyretic, antibacterial, antimicrobial, anti-viral, antioxidant, Cytotoxicity assay, Ant diabetic activities of phytochemicals .

\section{ACKNOWLEDGMENTS}

We would like to thank Department of Botany, Gujarat University for providing us the facilities for research work.

\section{REFERENCES}

[1] Kurian, J. C. (1995). Plants that heal. Pune. 


\section{International Journal of Research in Advent Technology, Vol.7, No.4, April 2019 \\ E-ISSN: 2321-9637 \\ Available online at www.ijrat.org}

[2] Chaudhri R.D. (1999); 1-3.,“ Herbal Drugs Industry", New Delhi, Eastern Publishers,

[3] Kurian, A., \& Sankar, M. A. (2007). Medicinal plants (Vol. 2). New India Publishing.

[4] Pushpangadan, P., \& George, V. (2010). Ethnomedical practices of rural and tribal populations of India with special reference to the mother and childcare.

[5] Mann, A., Banso, A., \& Clifford, L. C. (2008). An antifungal property of crude plant extracts from Anogeissus leiocarpus and Terminalia avicennioides. Tanzania Journal of Health Research, 10(1), 34-38.

[6] Anonymous (1998).Census of India 1991.Series to Andra Pradesh, District Census Handbook, Khammam, (Government of Andra Pradesh, Hydrabad). pp. 100

[7] Alice K. and Asha S. (2007). Medicinal Plants Horticulture Sciences, New India, New India publication agency. 2: 1

[8] Pathak S, Mishra JK. (2011). Some ethnomedicinal plants of Sheopur district, MP. Ind J Sci Res., 2: 133-134.

[9] Bhandari MM. (1990). Flora of Indian Desert. MPS Repros., Jodhpur, India, pp. 42.

[10] Arulanandraj, N., Punithavani, T., \& Indumathy, S. (2011). Pharmacognostic evaluation of the roots of Murva (Maerua oblongifolia). International Journal of Drug Formulation and Research, 2(4), 312-319.

[11] Rathore, J. S., Rathore, M. S., \& Shekhawat, N. S. (2005). Micropropagation of Maerua oblongifolia-a liana of arid areas. Phytomorphology, 55(3\&4), 241-247.

[12] Abdel-Mogib, M. (1999). A lupane triterpenoid from Maerua oblongifolia. Phytochemistry, 51(3), 445-448.

[13] Diallo, D., Sogn, C., Samaké, F. B., Paulsen, B. S., Michaelsen, T. E., \& Keita, A. (2002). Wound healing plants in Mali, the Bamako region. An ethnobotanical survey and complement fixation of water extracts from selected plants. Pharmaceutical Biology, 40(2), 117-128.

[14] Bussmann, R. W. (2006). Ethnobotany of the Samburu of Mt. Nyiru, South Turkana, Kenya. Journal of Ethnobiology and Ethnomedicine, 2(1), 35.

[15] Rahman, M. A., Mossa, J. S., Al-Said, M. S., \& Al-Yahya, M. A. (2004). Medicinal plant diversity in the flora of Saudi Arabia 1: a report on seven plant families. Fitoterapia, 75(2), 149-161.

[16] Abdel-Mogib, M., Ezmirly, S. T., \& El-Shamy, M. M. A. (1996). J. King Abdulaziz Univ. Sci., 8, 89
[17] Mogib, M.A. (1999). A lupane triterpenoid from Maerua oblongifolia. Phytochemistry, 51(3): 445448.

[18] V. Madhavan a, Amit Kumar Shukla a, Anita Murali b, Usha Ma, S. N. Yoganarasimhana, (2010) Antipyretic activity studies of two botanical sources of the drug Murva, A ntipyretic activity studies of two botanical sources of the drug Murva / Asian Journal of Traditional Medicines, , 5 (5)

[19] Shaheen, F., M. Ahmad, M.T.H. Khan, S. Jalil, A. Ejaz, M.N. Sultankhodjaev, M. Arfan, M.I. Choudhary and Atta-ur-Rahman, null, (2005). Alkaloids of Aconitum laeve and their antiinflammatory antioxidant and tyrosinase inhibition activities.Phytochemistry, 66: 935-940.

[20] Pham-Huy, L. A., He, H., \& Pham-Huy, C. (2008). Free radicals, antioxidants in disease and health. International journal of biomedical science: IJBS, 4(2), 89.

[21] Chan, E. W. C., Lim, Y. Y., \& Chew, Y. L. (2007). Antioxidant activity of Camellia sinensis leaves and tea from a lowland plantation in Malaysia. Food chemistry, 102(4), 1214-1222.

[22] Abu-Dahab, R., \& Afifi, F. (2007). Antiproliferative activity of selected medicinal plants of Jordan against a breast adenocarcinoma cell line (MCF7). Scientia Pharmaceutica, 75(3), 121-146.

[23] Huyke, C., Engel, K., Simon-Haarhaus, B., Quirin, K. W., \& Schempp, C. M. (2007). Composition and biological activity of different extracts from Schisandra sphenanthera and Schisandra chinensis. Planta medica, 73(10), 1116-1126.

[24] Lai, C. S., Mas, R. H., Nair, N. K., Majid, M. I. A., Mansor, S. M., \& Navaratnam, V. (2008). Typhonium flagelliforme inhibits cancer cell growth in vitro and induces apoptosis: an evaluation by the bioactivity guided approach. Journal of Ethnopharmacology, 118(1), 14-20.

[25] Jayaveera, K. N., Yoganandham, R. K., Govindarajula, Y., \& Kumanan, R. (2010). Phytochemical screenings, antibacterial activity and physico chemical constants of ethanolic extract of Euphorbia thymifolia Linn. Int J Pharm Pharm Sci, 2(3), 81-82.

[26] El-Mahmood, A. M., Doughari, J. H., \& Ladan, N. (2008). Antimicrobial screening of stem bark extracts of Vitellaria paradoxa against some enteric pathogenic microorganisms. African Journal of Pharmacy and Pharmacology, 2(5), 089-094.

[27] Lau, C. B. S., Ho, C. Y., Kim, C. F., Leung, K. N., Fung, K. P., Tse, T. F., ... \& Chow, M. S. S. (2004). Cytotoxic activities of Coriolus versicolor (Yunzhi) extract on human leukemia and lymphoma cells by 
induction of apoptosis. Life Sciences, 75(7), 797808.

[28] Arulanandraj, N., Punithavani, T., \& Indumathy, S. (2011). Pharmacognostic evaluation of the roots of Murva (Maerua oblongifolia). International Journal of Drug Formulation and Research, 2(4), 312-319.

[29] Hudson, J. B., Graham, E. A., \& Towers, G. H. N. (1994). Antiviral assays on phytochemicals: the influence of reaction parameters. Planta medica, 60(04), 329-332.

[30] Bajpai, S. K., \& Chandra, K. (1990). Studies on the antiviral properties of plants with special reference to Zingiber capitatum. Fitoterapia, 61(1), 3-8.

[31] Arulanandraj, C. N., Punithavani, T., \& Indumathy, S. (2011). Effect of murva (Maerua oblongifolia) on alloxan induced diabetes in rats. International Journal of Pharmaceutical Sciences and Research, 2(10), 2754.

[32] Hamayun, M., Khan, M. A., \& Begum, S. (2003). Marketing of medicinal plants of Utror-Gabral valleys, Swat, Pakistan. Ethnobotanical Leaflets, 2005(1), 44. 